\title{
Severe coagulation defect due to a dietary deficiency of vitamin $\mathrm{K}$
}

\author{
B. T. COLVIN AND M. J. LLOYD
}

From the Department of Haematology, The London Hospital Medical College, London E1 2AD, UK

SUMMARY A patient with multiple injuries developed a severe coagulation defect due to a deficiency of vitamin K. None of the usual predisposing factors was present and the patient's diet was very poor. Dietary deficiency of vitamin $\mathrm{K}$ and the importance of antibiotic therapy in its production are discussed.

Vitamin $\mathrm{K}$ deficiency is usually due to long-standing complete obstruction to the common bile duct or, more rarely, to malabsorption. Vitamin $\mathrm{K}$ dependent clotting factors are reduced by oral anticoagulants. Dietary deficiency of vitamin $\mathrm{K}$ has rarely been described and there has been some doubt whether it occurs in man as a clinical problem.

\section{Case report}

In February 1976 a 60-year-old woman was involved in a road accident. She sustained a head injury and compound fractures of both legs. Recovery was slow and for the next six months she remained drowsy and very reluctant to feed, her diet consisting mainly of orange and glucose drinks with a multivitamin preparation which does not contain vitamin $K$. Her compound fractures became infected and she was treated with penicillin in various forms, gentamicin, tetracycline, and co-trimoxazole (Septrin). She then developed long-standing intermittent diarrhoea which was treated with codeine phosphate. She also received a strong analgesic mixture regularly as it was thought likely that she would soon die.

All antibiotics were stopped and 46 days later (six months after the accident) she began to bleed per urethram. Bruising of the limbs was noted together with bleeding gums and purpura. A clinical diagnosis of scurvy was made initially but then it was realised that the patient had received ascorbic acid, $25 \mathrm{mg}$ daily, in the vitamin preparation and this diagnosis was not pursued further.

Results of haematological tests were as follows: Haemoglobin $9.0 \mathrm{~g} / \mathrm{dl}$; mean corpuscular volume 79 fl; white cell count $6.3 \times 10^{9} / 1$; platelet count $320 \times$

Received for publication 20 June 1977
109/1. Prothrombin time (PT) $273 \mathrm{~s}$; control $13 \mathrm{~s}$ : British Corrected Ratio 21.0. Kaolin cephalin clotting time (KCCT) $205 \mathrm{~s}$; control $39 \mathrm{~s}$. Thrombin time 10 $\mathrm{s}$; control $10 \mathrm{~s}$.

Specific coagulation factor assays were performed. Factors II, VII, IX and X were less than $1 \%$ and factor $\mathrm{V}$ was $76 \%$ of pooled normal control plasma. Factor VIII was normal at $1.28 \mathrm{u} / \mathrm{ml}$ by a two-stage method. Coagulation methods used were as described by Austen and Rhymes (1975).

There was a complete response of these abnormalities to vitamin $K_{1}$ (phylloquinone), $10 \mathrm{mg}$ intravenously daily for three days, the prothrombin ratio being 1.5 after 24 hours. After this the same dose was given orally.

The results of other investigations were:

\begin{tabular}{|c|c|c|}
\hline \multirow{3}{*}{$\begin{array}{l}\text { Plasma iron } \\
\text { Total iron binding } \\
\text { capacity }\end{array}$} & & Normal ra \\
\hline & $4 \mu \mathrm{mol} / 1$ & $13-32$ \\
\hline & $22 \mu \mathrm{mol} / 1$ & 44-67 \\
\hline Albumin & $27 \mathrm{~g} / 1$ & $37-52$ \\
\hline Calcium & $1.9 \mu \mathrm{mol} / 1$ & $2 \cdot 1-2 \cdot 6$ \\
\hline Inorganic phosphorus & $0.87 \mu \mathrm{mol} / 1$ & $0 \cdot 8-1 \cdot 4$ \\
\hline Serum folic acid & $1.6 \mu \mathrm{g} / 1$ & $3-20$ \\
\hline Serum vitamin $\mathbf{B}_{12}$ & $110 \mathrm{ng} / 1$ & $150-1,000$ \\
\hline
\end{tabular}

Stool culture showed normal faecal flora

A xylose tolerance test using a $5 \mathrm{~g}$ xylose load was normal.

\section{Discussion}

Nutritional deficiency of vitamin $\mathbf{K}$ was reported in four patients by Kark and Lozner (1939). In each of their cases the general nutritional state of the patient was very poor and scurvy was also diagnosed. Such haemorrhage as occurred was typical of scurvy and the prothrombin ratios were never greater than 1.5. Vitamin $\mathrm{K}$ given orally corrected the abnormal 
prothrombin ratios. Frick et al. (1967) performed a series of experiments on 10 'apoplectic' patients who were fed on glucose and water and all necessary vitamins except vitamin $K$. Seven developed moderate hypoprothrombinaemia after three to four weeks and these had been given antibiotics but three who had not received antibiotics showed no change in prothrombin times. After small replacement doses Frick concluded that the minimum daily requirement for vitamin $K_{1}$ lies between 0.03 and $1.5 \mu \mathrm{g} / \mathrm{kg}$ body weight. Barkhan and Shearer (1977) suggest a daily requirement of 0.1 to $0.5 \mu \mathrm{g} / \mathrm{kg}$ per day from their study of a patient with obstructive jaundice. Pineo $e t$ al. (1973) reported on 27 patients who developed vitamin $\mathbf{K}$ deficiency unexpectedly while in hospital, 22 patients having received antibiotics. Diets were poor and changes in prothrombin levels were often observed within seven days of admission or operation, often being associated with renal insufficiency. Penicillins and gentamicin were the antibiotics most commonly used. Prothrombin times were moderately prolonged, the mean time being $29 \mathrm{~s}$ in the 10 patients with major bleeding.

Sources of vitamin $\mathrm{K}$ in man are the diet and possibly products of intestinal bacteria. Traditionally the latter source is thought to be important but this view was challenged by the report of Udall (1965) who instilled $500 \mathrm{mg}$ of phylloquinone into the caecum of 10 patients anticoagulated with warfarin without any effect on the prothrombin time. The same dose was active by mouth. He also gave neomycin sulphate, $4 \mathrm{~g}$ daily by mouth, to 10 anticoagulated patients without any change in prothrombin time in four patients and only moderate prolongation in the other six. Shearer et al. (1974) reported that the net maximal absorption of an oral dose of vitamin $K_{1}$ in normal subjects was approximately $80 \%$ and support the view that a dietary source of vitamin $\mathrm{K}$ is essential.

The role of antibiotics in the production of hypoprothrombinaemia is not clear. For the antibiotics used in this case only one possible association unrelated to warfarin therapy was reported to the Committee on Safety of Medicines for the period 1964-75 (personal communication). Drug-induced steatorrhoea is nevertheless well described (Dobbins, 1968), and oral neomycin is known to precipitate bile salts and interrupt the micellar phase of lipid absorption. In high oral dosage mucosal damage occurs but parenterally administered neomycin does not have these effects. Merliss and Hoffman (1951) describe four cases of steatorrhoea associated with oral antibiotic therapy, including tetracycline, but there is no mention of any haemostatic defect occurring as a result and no biopsy data are given.

In the patient described, all the features of the previous literature are repeated. Diet was very poor and multiple antibiotics were given, although these were stopped more than six weeks before the diagnosis of vitamin $\mathrm{K}$ deficiency was made. Unlike in previous reports, vitamin $\mathrm{K}$ deficiency was profound, probably because of the length of time available for the deficiency to develop. After the administration of antibiotics diarrhoea became a problem and the values of plasma iron, calcium, phosphate, folic acid, and vitamin $\mathrm{B}_{12}$ are compatible with gross malnutrition or a malabsorption syndrome. Supportive treatment improved her condition and her diarrhoea resolved with a return of liver function tests to normal.

This account shows that dietary deficiency of vitamin $\mathrm{K}$ can occur in man and may be profound. If antibiotics are important in this situation a secondary malabsorption syndrome is a more likely cause than bowel sterilisation.

We acknowledge the assistance of Dr P. Barkhan in the preparation of this account.

\section{References}

Austen, D. E. G., and Rhymes, I. L. (1975). A Laboratory Manual of Blood Coagulation. Blackwell Scientific Publications, Oxford.

Barkhan, P., and Shearer, M. J. (1977). Metabolism of vitamin $\mathrm{K}_{1}$ (Phylloquinone) in man. Proceedings of the Royal Society of Medicine, 70, 93-96.

Dobbins, W. O. (1968). Drug induced steatorrhoea. Gastroenterology, 54, 1193-1195.

Frick, P. G., Riedler, G., and Brögli, H. (1967). Dose response and minimal daily requirement for vitamin $\mathrm{K}$ in man. Journal of Applied Physiology, 23, 387-389.

Kark, R., and Lozner, E. L. (1939). Nutritional deficiency of vitamin $\mathrm{K}$ in man. Lancet, 2, 1162-1164.

Merliss, R. R., and Hoffman, A. (1951). Steatorrhoea following the use of antibiotics. New England Journal of Medicine, 245, 328-330.

Pineo, G. F., Gallus, A. S., and Hirsh, J. (1973). Unexpected vitamin $\mathrm{K}$ deficiency in hospitalized patients. Journal of the Canadian Medical Association, 109, 880883.

Shearer, M. J., McBurney, A., and Barkhan, P. (1974). Studies on the absorption and metabolism of Phylloquinone (vitamin $\mathrm{K}_{1}$ ) in man. Vitamins and Hormones, 32, 513-542.

Udall, J. A. (1965). Human sources and absorption of vitamin $\mathrm{K}$ in relation to anti-coagulation stability. Journal of the American Medical Association, 194, 127129. 